ROCZNIKI TEOLOGICZNE

Tom LXVIII, zeszyt $11-2021$

DOI: https://doi.org/10.18290/rt216811-4

ANNA ZELLMA

\title{
AKTYWIZACJA MŁODZIEŻY SZKÓŁ PONADPODSTAWOWYCH W NAUCZANIU RELIGII - MIĘDZY TRADYCJĄ A WSPÓŁCZESNOŚCIĄ
}

\author{
MOBILISATION OF SECONDARY SCHOOL STUDENTS IN RELIGION TEACHING - \\ BETWEEN TRADITION AND MODERNITY
}

\begin{abstract}
A b stract. The analyses presented in this study focus on the quality of secondary school student mobilisation, which is recommended in the valid Core curriculum of the Catholic Church catechesis in Poland (2018). Attention was drawn to the obligatory set of catechetic objectives - general requirements, the contents of religion teaching - specific requirements, attitudes that should be developed in young people, correlation of religion teaching with school education, recommended conditions and methods of implementation of syllabus and cooperation of the educational environment (family, parish, etc.). The analysis of these issues attempted to prove that all elements of essence and methodology in the religion core syllabus can play an important role in the mobilisation of young people. It was pointed out that transmission of the theological and catechetical message and the theological language dominates. These solutions are enriched by correlation with school education, which can contribute to the mobilisation of youth. Unfortunately, little attention is often devoted to human experience and students' personal knowledge, which does not favour mobilisation. The new information and communication technologies are also undervalued, as they are mentioned in very general terms. Meanwhile, dominant are proposals of applying traditional methods of mobilising young people, such as problem methods, seeking and exploring. Proposals of forms and methods of young people's evangelisation are lacking. Such an approach to youth mobilisation oscillates between tradition and modernity. There are more traditional accents. Hence, the analysed proposals for mobilising secondary school students require supplementing at the level of developing syllabuses and textbooks for religion teaching..
\end{abstract}

Keywords: youth; religion teaching; secondary school; mobilizations; learning methods; activity; correlation.

Prof. dr hab. AnNa Zellma - Katedra Teologii Pastoralnej i Katechetyki, Wydział Teologii, Uniwersytet Warmińsko-Mazurski w Olsztynie; adres do korespondencji: ul. Kard. Hozjusza 15, 11-041 Olsztyn; e-mail: anna.zellma@uwm.edu.pl; ORCID: https://orcid.org/00000002-3612-3454. 
Aktywizacja w nauczaniu religii należy do kluczowych zagadnień metodycznych i dydaktycznych, o istotnym znaczeniu edukacyjnym i wychowawczym. Zajmuje ważne miejsce w teorii i praktyce ${ }^{1}$. Zarówno dydaktycy nauczania religii, jak i nauczyciele religii są zgodni co do znaczenia aktywnego udziału dzieci i młodzieży w toku lekcji religii ${ }^{2}$. Stąd też za obowiązujące wszystkich nauczycieli religii uznaje się prowadzenie zajęć w sposób aktywizujący uczniów. Zasada ta wiąże się ze stymulowaniem dzieci i młodzieży do aktywnego udziału w procesie nauczania-uczenia się i wychowania. Ma zastosowanie zarówno na poziomie teorii, jak i praktyki. W związku z powyższym uzasadnione wydaje się postawienie pytania o jakość zakładanej aktywizacji młodzieży szkół ponadpodstawowych w obowiązującej od 1 września 2020 roku Podstawie programowej katechezy Kościoła katolickiego w Pol$s c e^{3}$. Wymieniony dokument programowy zawiera m.in. obowiązkowy zestaw celów katechetycznych - wymagań ogólnych, treści nauczania religii wymagań szczegółowych na danym etapie edukacyjnym, a także określa postawy, jakie należy kształtować w uczniach ${ }^{4}$. Zwraca uwagę na korelację nauczania religii z edukacją szkolną. Podaje też wskazania do realizacji założeń programowych oraz współpracy środowisk wychowawczych (rodziny, szkoły, parafii) ${ }^{5}$. Wytyczne z Podstawy programowej katechezy Kościoła katolickiego $w$ Polsce odgrywają ważną rolę przy tworzeniu programów i podręczników do nauczania religii na poszczególnych etapach edukacji szkolnej. $\mathrm{W}$ ten sposób wymieniony dokument ukierunkowuje jakość nauczania religii w szkole, także w zakresie aktywizacji młodzieży szkół ponadpodstawowych.

Poszukując odpowiedzi na wyżej postawione pytanie, należy uwzględnić zarówno tradycyjne, jak też współczesne podejście do aktywizacji. Punktem

${ }^{1}$ Zob. np. Stanisław Kulpaczyński (red.), Aktywizowanie katechizowanych (Lublin: [s.n.], 1997); Stanisław Łabendowicz, Metodyka katechezy (Radom: „Spatium”, 2019); Tenże, „Realizacja zasady aktywności w strukturze procesu dydaktycznego”, Zeszyty Formacji Katechetów 2(2018): 63-76; Janusz Mastalski, Zasady edukacyjne w katechezie: na podstawie badań przeprowadzonych w krakowskich gimnazjach (Kraków: Wydawnictwo Naukowe PAT, 2002); Anna Zellma, Wielostronne aktywizowanie młodzieży w szkolnym nauczaniu religii. Studium w świetle „Programu nauczania religii katolickiej z 2001 roku” (Olsztyn: Wydawnictwo UWM, 2006).

${ }^{2}$ Stanisław Kulpaczyński, „25 opinii katechetów o 25 latach katechezy w szkole”, w XXV lat nauczania religii w polskiej szkole. Między nadzieja a rzeczywistościa, red. Marian Zając (Lublin: Natan, 2015), 205-227; Mastalski, Zasady edukacyjne w katechezie: na podstawie badań przeprowadzonych $w$ krakowskich gimnazjach.

${ }^{3}$ Konferencja Episkopatu Polski, Podstawa programowa katechezy Kościoła katolickiego w Polsce (Częstochowa: Edycja Świętego Pawła, 2018) [dalej: PPK].

${ }^{4}$ Zob. tamże; por. szerzej o tym np. w: Aleksandra Bałoniak (red.), Wokót nowej podstawy programowej i programu nauczania religii (Częstochowa: Święty Paweł, 2020).

${ }^{5}$ Tamże. 
odniesienia będą przede wszystkim założenia teoretyczne zawarte w obowiązującej od 1 września 2020 roku Podstawie programowej katechezy Kościoła katolickiego $w$ Polsce. Literatura przedmiotu stanowi uzupełnienie dla prowadzonych analiz. Korzystając z metody analizy materiałów źródłowych i literatury przedmiotu najpierw wyjaśni się rozumienie pojęcia „aktywizacja”. Następnie zostaną ukazane - wraz z ich oceną - zakładane w wyżej wymienionym dokumencie programowym cele i treści nauczania religii oraz zalecenia i wskazania metodyczne, które służą aktywizacji młodzieży szkół ponadpodstawowych. W tym kontekście - w uwagach końcowych - przedstawi się kwestie znaczące dla praktyki nauczania religii.

\section{WOKÓŁ ROZUMIENIA AKTYWIZACJI}

Analizując literaturę przedmiotu, można dostrzec brak zgodności co do zakresu znaczeniowego pojęcia „aktywizacja”. Badacze nie są też zgodni w kwestii wyodrębnianych rodzajów aktywności uczniów na lekcji ${ }^{7}$. Dlatego, chcąc uniknąć nieścisłości i problemów metodologicznych, należy dokonać uściślenia terminologicznego. Jan Szpet, omawiając zasadę wielostronnego aktywizowania uczniów zaznacza, że „aktywizacja polega na stymulowaniu wszystkich czynności składających się na proces dydaktyczny, na integrowaniu czynności i kierowaniu nimi"8. Podobne rozumienie aktywizacji można znaleźć w pracy Bronisława Twardzickiego. Ten katechetyk nie podaje jednak własnej definicji, lecz odwołuje się do propozycji J. Szpeta, którą uznaje za znaczącą dla ukazania specyfiki wszechstronnego i wieloczynnościowego aktywizowania katechizowanych uczniów9

Dla ukazania aktywizacji młodzieży szkół ponadpodstawowych - w ujęciu dokumentów programowych - szczególnie wartościowa jest definicja aktywizacji zaproponowana przez Mariana Śnieżyńskiego ${ }^{10}$, na którą powołują

${ }^{6}$ Zob. Ryszard Czekalski, Bibliografia katechetyczna 2001-2010 (Warszawa: Wydawnictwo UKSW, 2012); Ryszard Czekalski, Roman Murawski (oprac.), Bibliografia katechetyczna 1996-2000 (Warszawa: Wydawnictwo UKSW, 2002).

${ }^{7}$ Tamże. Zob. Radosław Chałupniak, Jerzy Kostorz, Waldemar Spyra (red.), Aktywizacja w katechezie. Szansa czy zagrożenie? (Opole: Redakcja Wydawnictw WT UO, 2002).

${ }^{8}$ Jan Szpet, Dydaktyka katechezy (Poznań: UAM, 1999), 102.

${ }^{9}$ Bronisław Twardzicki, Katechetyka formalna $w$ stużbie wiary (Przemyśl: Wydawnictwo Archidiecezji Przemyskiej, 2003), 148.

${ }^{10}$ Zob. np. Marian Śnieżyński, Dialog edukacyjny (Kraków: Wydawnictwo Naukowe PAT, 2001), 109 nn; Tenże, Zarys dydaktyki dialogu, wyd. 2 (Kraków: Wydawnictwo Naukowe PAT, 1998). 
się dydaktycy nauczania religii ${ }^{11}$. Zdaniem tego dydaktyka, ,aktywizacja” to „zespół świadomych oddziaływań nauczycielskich, mających swe źródło w doskonałym przygotowaniu merytoryczno-metodycznym i w zespole pożądanych cech osobowościowych nauczycieli, które wspomagane odpowiednimi właściwościami psychofizycznymi uczniów oraz sprzyjającymi warunkami obiektywnymi - pozwalają wyzwolić lub zintensyfikować aktywność dzieci i młodzieży" "2. Za uznaniem powyższej definicji - jako znaczącej dla analiz podjętych w niniejszym opracowaniu - przemawia fakt, iż jej Autor: 1) dokonał trafnej integracji propozycji czołowych polskich dydaktyków (m.in. Edwarda Fleminga, Wincentego Okonia) w zakresie rozumienia aktywizacji; 2) dopełnił pojęcie ,aktywizacja” desygnatami wskazującymi na podmiotowo-przedmiotowe czynniki warunkujące skuteczność oddziaływań aktywizujących uczniów oraz 3) podjął się empirycznej weryfikacji teorii wielostronnego nauczania. M. Śnieżyński przez wiele lat zajmował się powyższą tematyką także w kontekście nauczania religii w szkole, zwłaszcza dialogu edukacyjnego, w którym uczestniczy nauczyciel religii i uczniowie. Zaproponowane przez M. Śnieżyńskiego rozumienie pojęcia „aktywizacja” wskazuje na jej precyzję. Pozwala wyodrębnić różne rodzaje aktywizacji. Zazwyczaj dydaktycy nauczania religii, uwzględniając procesy poznawania, odkrywania, przeżywania i zmieniania rzeczywistości, wskazują na konieczność odwołania się do nich w holistycznie ukierunkowanym nauczaniu religii. Tak więc, w zależności od przyjęcia, co jest ową sferą podlegającą stymulacji, wyodrębniają i opisują aktywizację: recepcyjną, intelektualną, emocjonalną i praktyczną $^{13}$. Niekiedy dydaktycy nauczania religii łączą aktywność recepcyjną z intelektualną, określając je terminem ,aktywność poznawcza lub intelektualna" ${ }^{14}$. Słusznie akcentują, iż poznawanie i odkrywanie są integralnie ze sobą powiązane, co sprawia, iż uczeń, przyswajając wiedzę, może podejmować trud

${ }^{11}$ Zob. np. Labendowicz, Metodyka katechezy, 33-37; Zellma, Wielostronne aktywizowanie młodzieży w szkolnym nauczaniu religii, 30-83.

${ }^{12}$ Śnieżyński, Dialog edukacyjny, 109.

${ }^{13}$ Wyodrębniając i opisując poszczególne rodzaje aktywizacji, dydaktycy nauczania religii korzystają z badań prowadzonych w dydaktyce ogólnej. Por. np. Franciszek Bereźnicki, Dydaktyka szkolna dla kandydatów na nauczycieli (Kraków: Impuls, 2018); Marek Korgul, Dydaktyka dla katechetów (Świdnica: [s.n.], 2014); Czesław Kupisiewicz, Dydaktyka ogólna (Warszawa: Wyższa Szkoła Umiejętności Pedagogicznych i Zarządzania, 2000); Stanisław Łabendowicz, Dydaktyka katechezy (Radom: „Spatium", 2019); Wincenty Okoń, Wprowadzenie do dydaktyki ogólnej, wyd. 4, (Warszawa: Żak, 1998); Józef Półturzycki, Dydaktyka dla nauczycieli (Toruń: Wydawnictwo Adam Marszałek, 1999); Zellma, Wielostronne aktywizowanie młodzieży w szkolnym nauczaniu religii, $30 \mathrm{i} \mathrm{nn}$.

14 Tamże. 
samodzielnego myślenia, formułować hipotezy i weryfikować je na drodze eksperymentów, działań praktycznych i analiz porównawczych ${ }^{15}$.

Wyżej wymienione cztery rodzaje aktywizacji są integralnie ze sobą powiązane. Wyzwalają wielostronną aktywność własną uczniów, ciągle motywując nauczyciela religii do inicjowania interakcji edukacyjnych i stymulowania aktywności uczniów w zakresie konstruowania wiedzy, przeżywania wartości i działania praktycznego. Co więcej, przyczyniają się do efektywnego wspomagania wychowanków w kształtowaniu dojrzałej osobowości, w której ważne miejsce zajmują postawy.

\section{CELE KATECHETYCZNE - WYMAGANIA OGÓLNE I TREŚCI NAUCZANIA - WYMAGANIA SZCZEGÓŁOWE}

Aktywizacja młodzieży w nauczaniu religii jest procesem dydaktyczno-wychowawczym, który wiąże się bezpośrednio z celami katechetycznymi wymaganiami ogólnymi oraz treściami nauczania - wymaganiami szczegółowymi zapisanymi w dokumentach programowych. Cele i treści wywierają znaczny wpływ na dobór rozwiązań metodycznych. Stanowią podstawę do jasnego, jednoznacznego rozumienia i efektywnego planowania wszystkich czynności, wykonywanych w procesie nauczania religii zarówno przez nauczycieli religii, jak i uczniów. Dzięki należycie sformułowanym, ogólnym i szczegółowym celom katechetycznym nauczyciel religii i uczniowie wiedzą, do czego i w jaki sposób zmierzają oraz co powinni osiągnąć. Można więc przyjąć, że cele katechetyczne wyznaczają zakres treści nauczania religii. Decydują także o doborze form, metod i środków dydaktycznych. Ponadto pozwalają ocenić jakość i efektywność działań edukacyjnych. Dokładnie sformułowane cele katechetyczne są też czynnikiem motywującym uczniów.

Analizując obowiązującą Podstawe programowa katechezy Kościoła katolickiego $w$ Polsce w szkołach ponadpodstawowych, czyli w liceum, technikum i szkole branżowej, można zauważyć wyraźne ukierunkowanie na kształtowanie tożsamości chrześcijańskiej ${ }^{16}$. W tym kontekście zakłada się ewangelizację młodzieży. Za istotne uznaje się wspomaganie uczniów szkół ponadpodstawowych w dojrzewaniu w wierze. Ściśle powiązane z powyższymi celami nauczania religii jest wzbudzanie potrzeby i kształtowanie

\footnotetext{
15 Tamże.

${ }^{16}$ PPK, 95-100.
} 
umiejętności dawania świadectwa oraz podejmowania apologii wiary. Działania te zostają zintegrowane $\mathrm{z}$ odczytywaniem powołania i odkrywaniem miejsca w świecie, Kościele, narodzie, rodzinie. Uwidacznia się w nich troska o holistyczny rozwój młodzieży, w tym o kształtowanie postaw społecznych, religijnych, moralnych. Przekaz wiadomości i przetwarzanie informacji w umyśle uczniów koncentruje się wokół wiary jako relacji osobowej, treści wiary, zgodności postaw z deklarowaną wiarą, pogłębiania znajomości Biblii i Tradycji czy też odkrywania słowa Bożego jako źródła odpowiedzi na pytania egzystencjalne ${ }^{17}$. Stanowi jedną z płaszczyzn aktywizacji młodzieży. Wymaga powiązania z kształtowaniem hierarchii wartości w oparciu o Boże Objawienie. Młodzież potrzebuje bowiem pomocy w rozpoznawaniu i hierarchizacji wartości w celu dokonywania właściwych wyborów.

$\mathrm{W}$ związku z powyższym w nauczaniu religii w szkołach ponadpodstawowych zakłada się towarzyszenie uczniom w odkrywaniu powołania chrześcijańskiego. Podkreśla się potrzebę podejmowania działań, które służą wspieraniu młodzieży $\mathrm{w}$ odnajdywaniu miejsca $\mathrm{w}$ świecie oraz wychowaniu do odpowiedzialnego pełnienia ról w społeczeństwie. To z kolei wymaga ukazywania zróżnicowanych zadań, które wynikają z przyjęcia sakramentów świętych. Kwestie te, zdaniem autorów podstawy programowej nauczania religii w szkołach ponadpodstawowych, powinny być powiązane z kształtowaniem tożsamości eklezjalnej oraz przygotowaniem do podejmowania działań apostolskich. Dlatego zakłada się wychowanie do identyfikacji i odpowiedzialności za wspólnotę. W ramach kształtowania tożsamości eklezjalnej zaleca się przedstawianie wydarzeń z historii Kościoła (poznawanych w korelacji z nauczaniem historii $\mathrm{w}$ szkole) oraz ich religijną interpretację czy też powiązanie z żywotami świętych i ze współczesnością. Dzięki tak ukierunkowanym działaniom można pomagać młodzieży w odkrywaniu miejsca i zadań w Kościele. Celu tego nie da się jednak osiągnąć bez wyraźnego powiązania z przygotowaniem uczniów szkół ponadpodstawowych do podejmowania działań apostolskich. Chodzi tu zwłaszcza o „wprowadzenie do dojrzałego udziału w misji Chrystusa i Kościoła: kapłańskiej, prorockiej i królewskiej”18 oraz „budzenie potrzeby dawania świadectwa wiary i odpowiedzialności za misje" ${ }^{\prime 19}$.

Aby opisana teleologia nauczania religii $\mathrm{w}$ szkołach ponadpodstawowych była rzeczywiście w służbie aktywizacji młodzieży, winna być mocno powiąza-

\footnotetext{
17 Tamże, 99-100.

18 Tamże, 100.

${ }^{19}$ Tamże.
} 
na $\mathrm{z}$ egzystencjalnym wymiarem nauczania religii oraz $\mathrm{z}$ korelacją $\mathrm{z}$ edukacją szkolną. Wymagane są odpowiednie treści, które odwołują się do doświadczeń młodzieży, odpowiadają na potrzeby i pytania egzystencjalne oraz przyczyniają się do rozwijania umiejętności i kształtowania postaw. Wśród propozycji merytorycznych, zawartych w Podstawie programowej katechezy Kościoła katolickiego w Polsce, na szczególną uwagę zasługuje przekaz wiedzy dotyczącej chrześcijańskiej wizji człowieka i świata, dróg poznania Boga, interpretacji wybranych tekstów biblijnych, wiary i rozumu, wolności, piękna i harmonii, świętowania niedzieli, odpoczynku, natury człowieka, powołania człowieka w świecie i Kościele ${ }^{20}$. Niemniej istotne są treści skoncentrowane wokół problematyki sakramentów, oceny moralnej czynów ludzkich i uczuć, sumienia, cnót boskich i ludzkich, przykazań Bożych i kościelnych ${ }^{21}$. W tym kontekście proponuje się również podejmowanie takich zagadnień, jak: modlitwa, troska o potrzebujących, ubogich, uchodźców, dzieje Kościoła powszechnego i partykularnego, żywoty świętych, dobro wspólne, cztery zasady życia duchowego, rodzina, świadectwo chrześcijańskiego życia, dialog międzykulturowy i międzyreligijny, zaangażowanie chrześcijan w tworzenie kultury ${ }^{22}$.

Cele katechetyczne - wymagania ogólne i treści nauczania - wymagania szczegółowe w szkołach ponadpodstawowych zorientowane są zarówno na ucznia i różne środowiska, w których żyje, jak też na wierność Bogu. Nie można ich osiągnąc bez wyraźnego odwołania do treści przedmiotów nauczania w szkołach ponadpodstawowych. Korelacja z edukacją szkolną stanowi niezbędny, merytoryczny element w aktywizacji młodzieży. Dotyczy to zwłaszcza integrowania i uzupełniania zagadnień z zakresu języka polskiego, historii, wiedzy o społeczeństwie i wychowania do życia w rodzinie. Obok tego nie może zabraknąć odwołania do treści edukacji dla bezpieczeństwa, historii sztuki, historii muzyki, geografii, biologii, podstaw przedsiębiorczości. W tym kontekście - tam, gdzie to konieczne - działania korelacyjne powinny mieć charakter polemiki z treściami danego przedmiotu nauczanego w szkole. Tak ukierunkowane mogą przyczynić się do wieloaspektowego spojrzenia na rozwiązywane problemy czy podejmowane zagadnienia oraz emocjonalnie pozytywnego odniesienia do wiedzy odkrywanej podczas lekcji religii.

\footnotetext{
${ }^{20}$ Tamże, 100-123, 125-136.

${ }^{21}$ Tamże.

${ }^{22}$ Tamże.
} 
Zakładane cele i treści nauczania religii w szkołach ponadpodstawowych stanowią niezbędny element $\mathrm{w}$ procesie wspierania młodzieży $\mathrm{w}$ holistycznym rozwoju. Wyznaczają zakres samodzielności poznawczej uczniów i sprzyjają zaangażowaniu emocjonalnemu. W swej istocie, chociaż dotyczą współcześnie bardzo często kwestionowanego niezmiennego nauczania Kościoła na temat prawd wiary i norm moralnych, mogą okazać się interesujące przynajmniej dla części młodzieży. Wymagają jednak: 1) powiązania z osobistym doświadczeniem uczniów, posiadanym obrazem Kościoła i współczesnymi zagrożeniami cywilizacyjnymi; 2) zastosowania odpowiedniego języka (m.in. narracyjnego, sztuki, muzyki, mediów społecznościowych i tzw. świata wirtualnego); 3) organizowania sytuacji problemowych i wykorzystania nowoczesnych rozwiązań metodycznych ${ }^{23}$. Istnieje przy tym potrzeba oferowania młodzieży nowej propozycji wiary, odważnego i kreatywnego głoszenia Ewangelii, umożliwiania stawiania pytań, prowadzenia dialogu czy też duchowego towarzyszenia. Konieczne są też działania związane $\mathrm{z}$ odwołaniem do wiedzy osobistej uczniów nabytej poza lekcją religii. Tylko wtedy cele i treści nauczania religii, zakładane w Podstawie programowej katechezy Kościoła katolickiego, przyczynią się do aktywizacji młodzieży.

\section{PROPOZYCJE METODYCZNE}

Zalecane warunki i sposoby realizacji założeń programowych nauczania religii $\mathrm{w}$ szkole ponadpodstawowej, jako jeden $\mathrm{z}$ istotnych i niezastępowalnych składników planowania i realizacji lekcji religii, odgrywają ważną rolę w aktywizacji młodzieży. Mają jednak charakter bardzo ogólny. Autorzy Podstawy programowej katechezy Kościoła katolickiego w Polsce wskazują jedynie na grupy metod, które warto stosować w toku lekcji religii ${ }^{24}$. Nie podają konkretnych, przykładowych metod aktywizujących młodzież. Wśród proponowanych rozwiązań metodycznych dominują metody poszukujące i praktyczne oraz czytanie Pisma Świętego, Katechizmu Kościoła Katolickiego, dokumentów Kościoła, literatury religijnej i wyciąganie z nich wniosków. Metoda analizy różnych tekstów należy do tradycyjnych metod aktywizujących (głównie intelektualnie i emocjonalnie) uczniów. Podobny charakter mają, proponowane w Podstawie programowej katechezy Kościoła

\footnotetext{
${ }^{23}$ Por. Papieska Rada ds. Krzewienia Nowej Ewangelizacji, Dyrektorium o katechizacji (Kielce: Jedność, 2020), 244-245.

${ }^{24}$ Tamże, 123-125.
} 
katolickiego, metody poszukujące, ,prowadzące do «uwrażliwienia osób na ich najważniejsze doświadczenia, wspomaganie ich w ocenianiu w świetle Ewangelii pytań i potrzeb, jakie $\mathrm{z}$ nich wynikają oraz wychowanie ich do nowego stylu życia» (DOK152)"25. I chociaż zakładają one kreatywność młodzieży czy też odwołanie do doświadczeń młodzieży, to jednak należą do klasycznych metod aktywizujących. Uczenie się przez odkrywanie było już mocno postulowane w latach 60. i 70. XX wieku. Aby można było ocenić je jako współczesne, nowoczesne, potrzebne są odpowiednie wielostronnie aktywizujące techniki i środki dydaktyczne z zastosowaniem nowych technologii informacyjno-komunikacyjnych.

Podobną wartość mają zalecane w nauczaniu religii w szkołach ponadpodstawowych metody praktyczne i metody eksponujące. Pierwsza grupa metod koncentruje się na uczeniu się przez działanie, druga na uczeniu się przez przeżywanie. Autorzy Podstawy programowej katechezy Kościoła katolickiego w Polsce zaznaczają, że metody praktyczne należy dodatkowo łączyć z wykorzystaniem umiejętności uczniów w zakresie technologii informacyjno-komunikacyjnych ${ }^{26}$. Takie podejście świadczy o nowoczesnym rozumieniu metod praktycznych. Sama natomiast metoda projektów, którą w tym kontekście (jako przykładową) podają autorzy podstawy programowej, należy do metod problemowych i poszukujących, od dawna obecnych w dydaktyce nauczania religii. Zastosowanie tej metody w połączeniu $\mathrm{z}$ nowymi technologiami informacyjno-komunikacyjnymi nadaje jej nowy charakter. Z kolei, w odniesieniu do metod eksponujących, zaleca się ich zastosowanie w tradycyjny sposób - m.in. poprzez odwołanie do doświadczeń religijnych młodzieży. Takie wskazanie jest uzasadnione i poprawne metodycznie. Odwołanie do osobistych doświadczeń uczniów spełnia ważną rolę w procesie wielostronnej aktywizacji. Pozwala zaangażować całą osobę, a więc jej intelekt, uczucia, wolę. Motywuje też do działania. Interesujące i poprawne dydaktycznie są zalecenia, które dotyczą wykorzystania cyberprzestrzeni (np. wartościowych stron internetowych, portali katolickich) jako źródła treści religijnych. Brakuje tu jednak odniesienia do portali społecznościowych i platform edukacyjnych, które odgrywają ważną rolę we współczesnym nauczaniu religii.

Bardzo istotne jest dostrzeżenie znaczenia świadectwa katechety w nauczaniu religii. U podstaw znajduje się przekonanie, że zgodność czynów z głoszoną nauką wzmacnia działania dydaktyczne i wychowawcze oraz pobudza do osobistej refleksji i motywuje do zainteresowania się tematyką lekcji religii.

\footnotetext{
${ }^{25}$ Tamże, 124.

${ }^{26}$ Tamże.
} 


\section{UWAGI KOŃCOWE}

$\mathrm{W}$ analizowanym dokumencie programowym nauczania religii $\mathrm{w}$ szkołach ponadpodstawowych daje się zauważyć bogactwo treści katechizmowych i teologicznych, co rodzi pytanie o zasadność takiego podejścia do nauczania religii współczesnej młodzieży, która w zdecydowanej większości wykazuje obojętność religijną czy też coraz częściej deklaruje się jako osoba niepraktykująca lub/i niewierząca. Zbyt mało uwagi poświęca się ludzkim doświadczeniom oraz konieczności wychodzenia od rzeczywistości bliskiej młodzieży. W ten sposób treści, które służą aktywizacji młodzieży szkół ponadpodstawowych, nie zostają należycie uwzględnione. Również działania ewangelizacyjne wśród młodzieży szkół ponadpodstawowych są marginalizowane. Dominuje przekaz treści wiary i norm moralnych. Co więcej, pomija się zalecenia i wskazania dotyczące form i metod ewangelizacji w środowisku szkolnym (np. w ramach rekolekcji szkolnych, lekcji religii, zajęć pozalekcyjnych).

Podstawa programowa katechezy Kościoła katolickiego w Polsce wiele uwagi poświęca tradycyjnym rozwiązaniom metodycznym. Przypomina o ich znaczeniu i sposobie wykorzystania w praktyce. Nie ogranicza się jednak tylko do tych kwestii. Wskazuje na współczesne rozwiązania metodyczne z zastosowaniem nowych technologii informacyjno-komunikacyjnych. Nie poświęca im jednak szczególnej uwagi. Przeciwnie, podaje ogólne zalecenia i wskazania, pomijając te elementy, które stymulują aktywność współczesnej młodzieży, np. portale społecznościowe i mobilne aplikacje internetowe. Zapomina o znaczeniu dialogu edukacyjnego. Uzasadnione zatem wydają się twórcze działania autorów nowych serii podręczników i materiałów do nauczania religii ukierunkowane na wzbogacanie rozwiązań metodycznych o technologie informacyjno-komunikacyjne oraz różne odmiany rozmowy i dialogu.

W praktyce aktywizacja uczniów wymaga odpowiedniego języka, o czym zapominają twórcy podstawy programowej nauczania religii w szkołach ponadpodstawowych. Trzeba dowartościować język narracyjny, sztuki i muzyki, dźwięków, obrazów, porównań z życia wziętych oraz przytaczać różne historie. Unikać należy naukowego języka teologicznego, by w to miejsce dowartościować język egzystencjalny, zrozumiały dla młodzieży. Dowartościować należy też wiedzę osobistą ucznia i jego doświadczenia życiowe. Niemniej istotna jest postawa nauczyciela religii - animatora, doradcy, partnera w dyskusji, wspólnie z uczniami odkrywającego różne punkty widzenia rzeczywistości i uzgadniającego racje. Wysiłki katechety, zmierzające 
w tym kierunku, wymagają respektowania potrzeb i zainteresowań wychowanków oraz zastosowania różnych sposobów stymulowania twórczej aktywności uczniów. Nie może przy tym zabraknąć dialogu edukacyjnego i odpowiedniej postawy nauczyciela religii. Jednym z istotnych zadań nauczyciela religii jest tworzenie sytuacji edukacyjnych, które pozwalają młodzieży wykorzystać wiedzę z innych przedmiotów szkolnych oraz odkryć zdobycze nauki od strony moralnej i religijnej. Dowartościować trzeba też nie tylko nowoczesne i zróżnicowane środki audiowizualne, ale także nowe technologie informacyjno-komunikacyjne (w tym aplikacje mobilne). Zadanie to stoi m.in. przed twórcami kolejnych serii podręczników do nauczania religii w szkołach ponadpodstawowych.

Warto też empirycznie sprawdzić, czy i w jakim zakresie propozycja aktywizacji młodzieży szkół ponadpodstawowych w nauczaniu religii jest realizowana w praktyce szkolnej. W ten sposób będzie można oszacować wartość analizowanej podstawy programowej, a w przyszłości dokonać stosownych zmian. W procesie aktywizacji uczniów kluczową rolę spełniają nie tylko kompetencje merytoryczne, dydaktyczne i pedagogiczne, ale także świadectwo nauczyciela religii. Pogłębiona duchowość, więź z Bogiem i ze wspólnotą Kościoła, autentyczność, uwaga skoncentrowana na uczniach, świadectwo życia gwarantują dobrą aktywizację młodzieży. W związku z tym w procesie permanentnej formacji nauczycieli religii szczególną uwagę należy zwracać na zróżnicowane formy towarzyszenia nauczycielom religii w rozwoju osobowej i osobistej relacji z Bogiem.

\section{BIBLIOGRAFIA}

Bałoniak, Aleksandra (red.). Wokót nowej podstawy programowej i programu nauczania religii. Częstochowa: Święty Paweł, 2020.

Bereźnicki, Franciszek. Dydaktyka szkolna dla kandydatów na nauczycieli. Kraków: Impuls, 2018.

Chałupniak, Radosław, Jerzy Kostorz, Waldemar Spyra (red.). Aktywizacja w katechezie. Szansa czy zagrożenie? Opole: Redakcja Wydawnictw WT UO, 2002.

Czekalski, Ryszard, Roman Murawski (oprac.). Bibliografia katechetyczna 1996-2000. Warszawa: Wydawnictwo UKSW, 2002.

Czekalski, Ryszard. Bibliografia katechetyczna 2001-2010. Warszawa: Wydawnictwo UKSW, 2012.

Konferencja Episkopatu Polski. Podstawa programowa katechezy Kościoła katolickiego w Polsce. Częstochowa: Edycja Świętego Pawła, 2018.

Korgul, Marek. Dydaktyka dla katechetów. Świdnica: [s.n.], 2014.

Kulpaczyński, Stanisław (red.). Aktywizowanie katechizowanych. Lublin [s.n.], 1997. 
Kulpaczyński, Stanisław. „25 opinii katechetów o 25 latach katechezy w szkole”. W XXV lat nauczania religii $w$ polskiej szkole. Między nadzieja a rzeczywistościa, red. Marian Zając, 205-227. Lublin: Natan, 2015.

Kupisiewicz, Czesław. Dydaktyka ogólna. Warszawa: Wyższa Szkoła Umiejętności Pedagogicznych i Zarządzania, 2000

Łabendowicz, Stanisław. Dydaktyka katechezy. Radom: „Spatium”, 2019.

Łabendowicz, Stanisław. Metodyka katechezy. Radom: „Spatium”, 2019.

Łabendowicz, Stanisław. „Realizacja zasady aktywności w strukturze procesu dydaktycznego”. Zeszyty Formacji Katechetów 2 (2018): 63-76.

Mastalski, Janusz. Zasady edukacyjne $w$ katechezie: na podstawie badań przeprowadzonych w krakowskich gimnazjach. Kraków: Wydawnictwo Naukowe PAT, 2002.

Okoń, Wincenty. Wprowadzenie do dydaktyki ogólnej, wyd. 4. Warszawa: Żak, 1998.

Papieska Rada ds. Krzewienia Nowej Ewangelizacji. Dyrektorium o katechizacji. Kielce: Jedność, 2020

Półturzycki, Józef. Dydaktyka dla nauczycieli. Torun: Wydawnictwo Adam Marszałek, 1999.

Szpet, Jan. Dydaktyka katechezy. Poznań: UAM, 1999.

Śnieżyński, Marian. Dialog edukacyjny. Kraków: Wydawnictwo Naukowe PAT, 2001.

Śnieżyński, Marian. Zarys dydaktyki dialogu, wyd. 2. Kraków: Wydawnictwo Naukowe PAT, 1998.

Twardzicki, Bronisław. Katechetyka formalna w stużbie wiary. Przemyśl: Wydawnictwo Archidiecezji Przemyskiej, 2003.

Zellma, Anna. Wielostronne aktywizowanie młodzieży w szkolnym nauczaniu religii. Studium $w$ świetle „Programu nauczania religii katolickiej z 2001 roku”. Olsztyn: Wydawnictwo UWM, 2006.

\section{AKTYWIZACJA MŁODZIEŻY SZKÓŁ PONADPODSTAWOWYCH W NAUCZANIU RELIGII - MIĘDZY TRADYCJĄ A WSPÓŁCZESNOŚCIĄ}

\section{Streszczenie}

Analizy, podjęte w niniejszym opracowaniu, koncentrują się wokół jakości aktywizacji młodzieży szkół ponadpodstawowych, którą zaleca się w obowiązującej Podstawie programowej katechezy Kościoła katolickiego w Polsce (2018). Zwrócono uwagę na obowiązkowy zestaw celów katechetycznych - wymagań ogólnych, treści nauczania religii - wymagania szczegółowe, postawy, jakie należy kształtować w młodzieży, korelację nauczania religii z edukacją szkolną, zalecane warunki i sposoby realizacji założeń programowych oraz współpracę środowisk wychowawczych (rodziny, parafii). Analizując wymienione kwestie próbowano dowieść, że wszystkie elementy merytoryczne i metodyczne, zapisane w podstawie programowej nauczania religii, mogą odgrywać ważną rolę aktywizującą młodzież. Zauważono, że dominuje przekaz wiadomości teologicznych i katechizmowych oraz język teologiczny. Wymienione rozwiązania merytoryczne zostają wzbogacone o korelację z edukacją szkolną, która może przyczynić się do aktywizacji młodzieży. Mało uwagi poświęca się jednak doświadczeniu ludzkiemu oraz wiedzy osobistej uczniów, co nie sprzyja aktywizacji. Również niedowartościowane są nowe technologie informacyjno-ko- 
munikacyjne, o których wspomina się bardzo ogólnie. Dominują natomiast propozycje zastosowania tradycyjnych metod aktywizujących młodzież, takich jak metody problemowe, poszukujące, eksponujące. Brakuje propozycji dotyczących form i metod ewangelizacji młodzieży. Takie podejście do aktywizacji młodzieży oscyluje między tradycją a współczesnością. Więcej przy tym jest akcentów tradycyjnych. Stąd też analizowane propozycje aktywizacji młodzieży szkół ponadpodstawowych wymagają uzupełnienia na poziomie tworzenia programów i podręczników do nauczania religii.

Słowa kluczowe: młodzież; nauczanie religii; szkoła ponadpodstawowa; aktywizacja; metody nauczania; aktywność; korelacja. 